\title{
Allergic contact dermatitis to triclosan-coated suture material
}

\section{Fathima F. Ismail (1), Rosemary Nixon (2)}

(1) Sinclair Dermatology, East Melbourne, Victoria, Australia

(2) Occupational Dermatology Research and Education Centre, Skin Health Institute, Carlton, Victoria, Australia

Correspondence:

Dr Fathima F. Ismail, Sinclair Dermatology

2 Wellington Pde, Melbourne, Victoria 3002, Australia

f.ferial.ismail@gmail.com

Key words: Allergic contact dermatitis, case report, Triclosan-coated sutures, Triclosan, Sutures, Wound Breakdown

The authors have no conflicts of interest to declare.

We present a case of presumed allergic contact dermatitis (ACD) to triclosan-coated Vicryl Plus and Monocryl Plus suture material causing breakdown of an abdominal wound.

\section{Case report}

A 53-year-old theatre nurse presented to our patch testing clinic. She had a history of atopy, with asthma, atopic dermatitis and allergic rhinitis since childhood. She had a complex medical history including endometriosis with bowel adhesions, and ruptured Achilles and hamstring tendons. She had previously tolerated tendon repairs using nylon and silk sutures, however when she had a breast reduction using triclosan-coated Monocryl Plus sutures, she developed redness and swelling at the surgical site.

This is the author manuscript accepted for publication and has undergone full peer review but has not been through the copyediting, typesetting, pagination and proofreading process, which may lead to differences between this version and the Version of Record. Please cite this article as doi: $10.1111 / \operatorname{cod} .13476$

This article is protected by copyright. All rights reserved. 
She recently underwent an abdominal hysterectomy using triclosan-coated Vicryl Plus and Monocryl Plus sutures. Within 24 hours of surgery she developed redness and swelling at the surgical site, which progressed to breakdown of the wound. She was re-hospitalised for 8 weeks, underwent suture removal and multiple vacuum dressing changes under general anaesthesia. She subsequently developed a large abdominal hernia which still requires repair. Patch testing revealed a positive reaction to triclosan $2 \%$ pet., and she was diagnosed with ACD to triclosan-coated sutures.

\section{Discussion}

Triclosan is an antimicrobial agent which is commonly used in Australia in many personal care products, cleaning agents and in the healthcare setting ${ }^{1}$. It is a known irritant to the skin, eyes and respiratory tract in humans ${ }^{1}$. As a result of its widespread use, it has become ubiquitous in the environment and has been banned in the United States by the Food and Drug Administration (FDA) for use in household products because of concerns about antimicrobial resistance ${ }^{2}$.

Triclosan-coated absorbable sutures were first approved for use by the FDA in 2002 to reduce the risk of surgical site infection ${ }^{3}$. Available varieties of triclosan-coated suture material include Vicryl Plus, Monocryl Plus and PDS Plus Antibacterial sutures ${ }^{3}$. A recent systematic review and meta-analysis concluded that triclosan-coated sutures were effective in reducing surgical site infections ${ }^{4}$. The World Health Organization (WHO) and Centers for Disease Control and Prevention (CDC) guidelines for the prevention of surgical site infection recommend the use of triclosan-coated sutures, based on low-tomoderate quality evidence ${ }^{5,6}$.

Triclosan has a low sensitising potential and ACD is uncommon. In a retrospective analysis of 113162 patients patch tested with triclosan $2 \%$ pet., a positive reaction was observed in only $363(0.32 \%)$ of patients, however $54 \%$ of positive reactions were considered clinically relevant ${ }^{7}$. A review of the English-language literature revealed one case report of a delayed-type allergic reaction to triclsoancoated suture material ${ }^{8}$. Our experience suggests that practitioners should consider the rare possibility of ACD to triclosan-coated suture material, in the setting of a post-operative skin reaction.

This article is protected by copyright. All rights reserved. 


\section{References}

1. Australian Government Department of Health - National Industrial Chemicals Notification and Assessment Scheme. Triclosan 2009. https://www.nicnas.gov.au/chemicalinformation/factsheets/chemical-name/triclosan. Accessed November 10, 2019.

2. McNamara PJ, Levy SB. Triclosan: an Instructive Tale. Antimicrob Agents Chemother. 2016 ;60(12):7015-16.

3. Dennis $C$, Sethu $S$, Nayak $S$ et al. Suture materials - Current and emerging trends. J Biomed Mater Res A. 2016;104(6):1544-59.

4. Ahmed I, Boulton AJ, Rizvi S et al. The use of triclosan-coated sutures to prevent surgical site infections: a systemiatic review and meta-analysis of the literature. BMJ Open. 2019 Sep;9(9):e029727.

5. World Health Organization. Global guidelines on the prevention of surgical site infection 2016. https://www.who.int/gpsc/ssi-prevention-guidelines/en/. Accessed November 10, 2019.

6. Centers for Disease Control and Prevention. Guideline for the Prevention of Surgical Site Infection 2017. https://jamanetwork.com/journals/jamasurgery/fullarticle/2623725. Accessed November 10, 2019.

7. Buhl T, Fuchs T, Geier J. Contact hypersensitivity to triclosan. Ann Allergy Asthma Immunol. 2014;113(1):119-20.

8. Bhutani T, Jacob SE. Triclosan: a potential allergen in suture-line allergic contact dermatitis. Dermatol Surg. 2009;35(5):888-9.

This article is protected by copyright. All rights reserved. 


\section{University Library}

\section{- M M I E R R V A gateway to Melbourne's research publications}

Minerva Access is the Institutional Repository of The University of Melbourne

Author/s:

Ismail, FF;Nixon, R

Title:

Allergic contact dermatitis to triclosan-coated suture material.

Date:

2020-05

Citation:

Ismail, F. F. \& Nixon, R. (2020). Allergic contact dermatitis to triclosan-coated suture material.. Contact Dermatitis, 82 (5), pp.330-331. https://doi.org/10.1111/cod.13476.

Persistent Link:

http://hdl.handle.net/11343/275373 